\title{
Real-Time RT PCR Evaluation of the Xylitol Effect on the Expression of Streptococcus pneumoniae cpsB, cpsD and psaA Genes
}

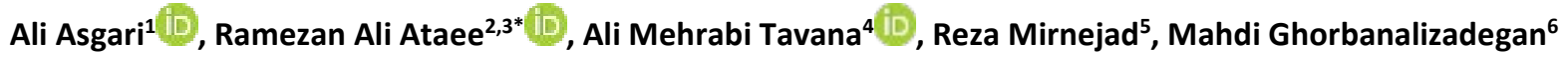

1. MSc of Medical Microbiology, Faculty of Medicine, Baqiyatallah University of Medical Sciences, Tehran, Iran.

2. Professor of Department of Medical Microbiology, Faculty of Medicine, and Applied Microbiology Research Center, System Biology and Poisonings Institute, Baqiyatallah University of Medical Sciences, Tehran, Iran.

3. Professor of Department of Medical Microbiology, and Hospital Research Development Committee, Baqiyatallah University of Medical Sciences, Tehran, Iran

4. Professor of Medical Microbiology, Faculty of Medicine and Health Management Research Center, Baqiyatallah University of Medical Sciences, Tehran, Iran.

5. Molecular Biology Research Center, Systems biology and poisonings institute, Baqiyatallah University of Medical Sciences, Tehran, Iran

6. Assistant professor of Medical Microbiology, Faculty of Medicine, and Applied Microbiology Research Center, System Biology and Poisonings Institute, Baqiyatallah University of Medical Sciences, Tehran, Iran

\section{ABSTRACT}

Background and Aim: The major pneumococcal pathogenesis factor is the capsular polysaccharide. the production of polysaccharide is regulated by $\operatorname{cps} B$ and $c p s D$ genes. Thus, every agent that induce or inhibition of expression of these genes probably increased pathogenesis of bacteria, intracellular survival and vis versa. The aim of this study was to assay the effect of Xylitol on Streptococcus pneumoniae cpsB, cpsD, psaA and aroE genes expression by Real Time RT-PCR.

Materials and Methods: During 2019 in Baqiyatallah university laboratories, 20 clinical isolates and a reference strain Streptococcus pneumoniae (ATCC 6305) were studied. To assay the effect of Xylitol and fructose، different concentration of these sugars were exposed to BHI Broth media. Thereafter, the bacterial suspension was added to $5 \%$ Xylitol, $5 \%$ Xylitol + $5 \%$ fructose and control medium for 3hours. RNA was extracted and cDNA synthesis was carried out. Then, the $\operatorname{cps} B, \operatorname{cps} D$ and psaA genes expression levels were measured.

Results: The mean of $c p s B$ gene expression ratio in presence of the $\% 5$ Xylitol treated media compared with those in the control media and $\% 5 \mathrm{Xylitol}+5 \%$ fructose were 0.022 and 0.027 respectively.

The means of the $c p s D$ and $p s a A$ genes expression ratio in the $\% 5$ Xylitol treated media compared with those in the control media and \% 5 Xylitol + 5\% fructose were 1.659 and 0.056 , and 0.633 and 3.294 respectively.

Conclusion: Our finding revealed that, the $5 \%$ Xylitol inhibit the $c p s B$ gene expression properly. Therefore, it is possible to use of Xylitol for reductive on $c p s B$ gene expression and superficial pneumococcal infections control.

Keywords: Capsular genes, RT Real-Time PCR, Streptococcus pneumoniae, Xylitol



Use your device to scan and read the article online

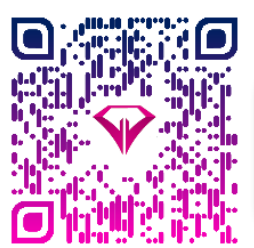

Asgari A, Ataee R, Tavana A M, Mirnejad R, Ghorbanalizdgan M. Real-time RT PCR Evaluation of the Xylitol Effect on the Expression of Streptococcus pneumoniae cpsB,cpsD and psaA Genes. Iran J Med Microbiol. 2021; 15 (4) :392-399

\section{Download citation: $\underline{B i b T e X}$ | $\underline{\text { RIS | EndNote | Medlars | ProCite | Reference Manager | RefWorks }}$}
Send citation to:
\% Mendeley
(2) Zotero
RefWorks 
Introduction

Streptococcus pneumoniae (S. pneumoniae) is an important human pathogen and a leading cause of morbidity and mortality worldwide (1). Invasive and noninvasive infectious diseases caused by $S$. pneumoniae strains such as meningitis, sepsis, bacteremia, pneumonia, sinusitis, acute otitis media in young children, elderly, and patients with immunodeficiency are increased $(2,3)$. In previous studies, the frequency of pneumococcal meningitis in elderly patients was reported more than $35 \%$ (4-6).

The main virulence factor of the S. pneumoniae is capsular polysaccharide which protects the bacteria against phagocytosis and plays an important role in colonization the bacterium on the upper airway (7). Thus, expression of polysaccharide capsule genes is essential for survival in against of the superficial immune, and enhances the virulence and pathogenicity.

Currently, the strategy for the prevention of lifethreatening pneumococcal disease, is based on the immunogenicity of polysaccharide capsule and the production of capsule base vaccines and existing vaccines (PCV7, PCV10, PCV13 and PPSV23) which made from capsule antigens (8). However, the causes such as the spread of serogroups, and emergence of new serotypes and serotype diversity (9) have reduced the efficacy of vaccines. Therefore, the use of vaccine in all cases could not be a good solution for preventing pneumococcal disease and its morbidity and mortality. In addition, the development of antibiotic resistance has increased the therapeutic problems (10). This bacterium has been resistant to many common antibiotics, therefore, since the production of polysaccharide capsules are introduced as the most important pathogenicity and virulence factor $(11,12)$. Several study on capsular synthesis mechanisms and also inhibit expression the involve genes were more considered (11).

Based on available data, in most serotypes, the capsule locus is located in the same region between the genes $\operatorname{dex} B$ and aliA locuses. The first four genes of this locus are conserved and named as: $c p s A, c p s B$, cps $C$ and $c p s D$, and thus, to determine the level of expression of the capsular genes locus are very important, $(13,14)$. It is well known that the $c p s B$ and $c p s D$ genes, plays major role in regulating the capsular synthesis and production (15)

It is reported that; Xylitol is a five-carbon sugar alcohol $(16,17)$ and have affected the bacterial growth and blocked the adhesion property of $S$. pneumoniae $(18,19)$. Research results have shown that Xylitol can prevent acute otitis media infections in children (20). Some research results revealed that psaA gene produces a $37-k D a$ protein called Pneumococcal surface adhesin $A$ (21), which acts as a superficial protein for binding of $S$. pneumoniae to mucosal cells $(22,23)$. As a result, it is reported that the psaA gene is also involved in the disease. Since, all pathogenic S. pneumonia have been shown to have this gene (24). Thus, the purpose of this study was assayed the effect of different concentration of Xylitol on the expression of the $c p s D$ and $p s a A$ genes. If the genes were inhibited, probably Xylitol can be used as complementary treatment with no any side effects against the S. pneumoniae superficial infection hopefully.

\section{Materials and Methods}

\section{Bacterial strain}

This investigation was carried out during the year 2019 in Baqiyatallah university complex laboratories. A reference strain of $S$. pneumoniae (ATCC 6305, purchase from Baharafshan Laboratory, Tehran, Iran), and twenty S. pneumoniae clinical isolates which previously were identified and their serotypes were reported $(25,26)$ was used. In separately manner, the lyophilized bacteria vials in aseptic conditions were dissolved in $1 \mathrm{ml} \mathrm{BHI}$ - broth media (Merck Co, Cat No.110493). Then $50 \mu \mathrm{L}$ of the suspension was transferred into Blood agar (Merck Co, Cat No.110886) which supplemented by $5 \%$ sheep blood and incubated at $37^{\circ} \mathrm{C}$ in a $5 \% \mathrm{CO}_{2}$ atmosphere for 24 hours. After overnight incubation, bacterial colonies were harvested and transferred into $3 \mathrm{ml}$ of $\mathrm{BHI}$ broth media containing $0.2 \%$ glucose and supplemented with $10 \%(\mathrm{vol} / \mathrm{vol})$ FBS (Fetal bovine serum) and incubated at $37^{\circ} \mathrm{C}$ in a $5 \% \mathrm{CO}_{2}$ atmosphere until the $\mathrm{OD}_{650}$ had been reached equal $0.5 \mathrm{McF}$ arland approximately for 5 hours. For each strain the bacterial suspension as the same of standard 0.5 McFarland $\left(10^{7} \mathrm{CFU} / \mathrm{mL}\right)$ were considered. In order to confirmamtic assay for all strain of the $S$. pneumoniae, a standard diagnostic procedure was carried out based on previously report $(27,28)$.

However, for each reaction the $300 \mu \mathrm{L}$ of bacterial suspension was added to $3 \mathrm{ml}$ of test media that were prepared by adding various sugar alcohol or sugar concentrations (Table-1). The test tubes were incubated at $37^{\circ} \mathrm{C}$ in $5 \% \mathrm{CO}_{2}$ atmosphere for about 3 hours. In order to obtain proper concentration cells and the desired RNA level, the contents of each test medium was centrifuged in $4^{\circ} \mathrm{C}$ for $3 \mathrm{~min}$ at $12000 \mathrm{~g}$ that supernatant containing the $\mathrm{BHI}$ broth was discarded and the resulting sediment was used to RNA extraction.

\section{Sugars stock solution preparation and sterilization}

In this research, the $40 \%$ stock solution of each sugar was prepared separately. Tested sugars were sterilized by filtration $(0.22 \mu \mathrm{m}$ pore-sized filter; Millipore.). Afterward certain amount was added to relat- 
ed test tubes. The Xylitol concentration used in this study were chosen on the basis of a previous study (19).

\section{RNA Extraction}

The kit of the TRIzol ${ }^{\circledR}$ Reagent solution (Cat No.15596-026; Ambion; USA) was used in order to extract
RNA. It should be noted that in the whole process of extraction of RNA, it is necessary to note that due to the abundance of the RNase enzyme in the environment and the sensitivity of RNA, moreover to use filter micropipette tips and RNase free micro tubes, and the whole process is done alongside the ice.

Table 1. Media and ingredients used for bacterial growth and RNA extraction. The volume and different concentrations of Xylitol, Fructose and Glucose were prepared from the stoke solution.

\begin{tabular}{|c|ccc|c|}
\hline Media & BHI broth & FBS & Sugar & Total volume \\
\hline BHI broth + 5\% Xylitol & $2425 \mu \mathrm{L}$ & $200 \mu \mathrm{L}$ & $375 \mathrm{~L}$ \\
\hline BHI broth & $2050 \mu \mathrm{L}$ & $200 \mu \mathrm{L}$ & $\begin{array}{c}375 \mu \mathrm{L} \text { Xylitol and } \\
375 \mu \mathrm{L} \text { fructose }\end{array}$ \\
\hline$+\mathbf{5 \%}$ fructose + $\mathbf{5} \%$ Xylitol & $2800 \mu \mathrm{L}$ & $200 \mu \mathrm{L}$ & $3000 \mu \mathrm{L}$ \\
\hline BHI broth Glucose -free (Control) & $3000 \mu \mathrm{L}$ \\
\hline
\end{tabular}

Based on the kit procedure, the RNA was extracted and stored at minus $70^{\circ}$ degree centigrade. The probable DNA contamination, the extracted total RNA was subjected to treat by Dnase1 enzyme (Cat No. PR891627; GENEALL; South Korea). As follows: $1 \mu \mathrm{L}$ of DNase I, 10x enzyme was added to $1 \mu \mathrm{g}$ extracted RNA in a RNase free micro tubes. $1 \mu \mathrm{L}$ of buffer $10 \mathrm{x}$ was added and the final volume with DEPC reached $10 \mu \mathrm{L}$ and incubated for 30 minutes at $37^{\circ} \mathrm{C}$. The reaction was completed by adding $1 \mu \mathrm{L}$ of $50 \mathrm{mM}$ EDTA solution and incubation at $65^{\circ} \mathrm{C}$. in order to analysis of the quality and quantity of the extracted RNA, the absorbance of 1.9 to 2 at 280/260 ratio revealed the purity of extracted total RNA by using Nano drop device (ND1000; Thermo). In order to determine the quantification extracted specimens, the concentration was calculated according the absorbance at $260 \mathrm{~nm}$.
To evaluate the quality of extracted RNAs, samples were run in agarose gel $1 \%$ (100 volts). The extracted RNA has shown a good quality, it will have two bands in gel, including 16srRNA and 23srRNA band. After that, all RNAs samples were rapidly converted to cDNA.

\section{cDNA Synthesis}

For cDNA synthesize, the PrimeScript ${ }^{T M}$ RT reagent Kit (Cat No. RR037A; TAKARA; Japan) was used. The reaction mixture was prepared according to the instruction of the kit (Table-2). Briefly, this mixture was incubated $15 \mathrm{~min}$ at $37^{\circ} \mathrm{C}$ for rverse transcription and then for inactivation of reverse transcriptase was incubated 5 secoun at $95^{\circ} \mathrm{C}$. To prevent contamination and experimental error until before the Real-Time PCR, wasn't use from specific primers for each of the genes and there were three total cDNA types.

Table 2. The Reagents and gradients utilized to synthesis cDNA.

\begin{tabular}{|c|c|c|c|}
\hline & Reagent & Amount & concentration \\
\hline & 5X Prime Script Buffer & $2 \mu \mathrm{L}$ & $1 X$ \\
\hline & Prime Script RT Enzyme Mix I & $0.5 \mu \mathrm{L}$ & - \\
\hline & Oligo dT Primer & $0.5 \mu \mathrm{L}$ & $50 \mu \mathrm{M}$ \\
\hline & Random 6 mers & $0.5 \mu \mathrm{L}$ & $100 \mu \mathrm{M}$ \\
\hline \multirow{3}{*}{$\begin{array}{l}\text { Total } \\
\text { RNA }\end{array}$} & Extracted from control media & \multirow{3}{*}{$3.5 \mu \mathrm{L}$} & $454.4 \mu \mathrm{L} / \mathrm{ng}$ \\
\hline & $\begin{array}{l}\text { Extracted from media containing } \\
\qquad \mathbf{5 \%} \text { Xylitol }\end{array}$ & & $395.8 \mu \mathrm{L} / \mathrm{ng}$ \\
\hline & \multicolumn{2}{|l|}{$\begin{array}{l}\text { Extracted from media containing } \\
\qquad 5 \% \text { fructose }+5 \% \text { Xylitol }\end{array}$} & \\
\hline \multicolumn{2}{|r|}{ RNase Free $\mathrm{DH}_{2} \mathrm{O}$} & $3 \mu \mathrm{L}$ & - \\
\hline \multicolumn{2}{|r|}{ Total volume } & $10 \mu \mathrm{L}$ & - \\
\hline
\end{tabular}

\section{RT Real Time PCR Performance}

For this purpose, specific primers were designed with GenScript software for amplify target genes
( $c p s B, c p s D$ and $p s a A)$, and to be synthesized were ordered (Macrogen; South Korea) (Table-3).

Briefly, $5 \mu \mathrm{L}$ of synthesized cDNA was used in RealTime PCR by applying the Real Q Pluse 2X Master Mix 
Green low ROX ${ }^{\mathrm{TM}}$ with SYBR ${ }^{\circledR}$ Green (Cat No. A323499; Ampliqon; Denmark) and the Exicycler ${ }^{\text {TM }} 96$ Real-Time Quantitative Thermal Block (Cat No. A-2060; BIONEER;
Republic of Korea). The therm cycler programs and protocols and gradients reagent were used according the kit instruction.

Table 3. Characteristics of Designed primers for set up the RT Real Time PCR

\begin{tabular}{|c|c|c|c|c|c|c|}
\hline \multicolumn{2}{|c|}{ Primer } & $\begin{array}{c}\text { Sequence } \\
5^{\prime}-3^{\prime}\end{array}$ & GC\% & $\operatorname{Tm}\left({ }^{\circ} \mathrm{C}\right)$ & $\begin{array}{l}\text { Amplicon } \\
\text { size }\end{array}$ & Concentration \\
\hline \multirow{2}{*}{$\begin{array}{c}\text { cpsB } \\
\text { (wzh) }\end{array}$} & Forward & TAGATGACGGTCCCAAGTCA & $50 \%$ & $58.4^{\circ} \mathrm{C}$ & \multirow{2}{*}{$202 \mathrm{bp}$} & $5 \mathrm{Pmol} / \mu \mathrm{L}$ \\
\hline & Reverse & GCGCCATAAGCAATGACTAA & $45 \%$ & $56.4^{\circ} \mathrm{C}$ & & $5 \mathrm{Pmol} / \mu \mathrm{L}$ \\
\hline \multirow{2}{*}{$\begin{array}{l}\text { CpsD } \\
\text { (wze) }\end{array}$} & Forward & CCAAACCCTACAGCCTTGTT & $50 \%$ & $58.4^{\circ} \mathrm{C}$ & \multirow{2}{*}{$159 b p$} & $5 \mathrm{Pmol} / \mu \mathrm{L}$ \\
\hline & Reverse & TGTTACCAAGATGGACGCAT & $45 \%$ & $56.4^{\circ} \mathrm{C}$ & & $5 \mathrm{Pmol} / \mu \mathrm{L}$ \\
\hline \multirow{2}{*}{$p s a A$} & Forward & GTAGCATGTGCTAGCGGAAA & $50 \%$ & $58.4^{\circ} \mathrm{C}$ & \multirow{2}{*}{$254 b p$} & $5 \mathrm{Pmol} / \mu \mathrm{L}$ \\
\hline & Reverse & TTTGTAAACCAAGCATTGCC & $40 \%$ & $54.3^{\circ} \mathrm{C}$ & & $5 \mathrm{Pmol} / \mu \mathrm{L}$ \\
\hline \multirow{2}{*}{ aroE } & Forward & TTTGGCATCAATCTGTCCAT & $40 \%$ & $54.3^{\circ} \mathrm{C}$ & \multirow{2}{*}{$286 b p$} & $5 \mathrm{Pmol} / \mu \mathrm{L}$ \\
\hline & Reverse & AAACGGAACGAACAAAGACC & $45 \%$ & $56.4^{\circ} \mathrm{C}$ & & $5 \mathrm{Pmol} / \mu \mathrm{L}$ \\
\hline
\end{tabular}

However, The Real-Time PCR was carried out in accordance with the instructions of the utilized kit. Real Time PCR was performed two times and every sample was run as triplicates in each time. Finally, the average $C_{T}$ was totally obtained from the 6 collected $\mathrm{C}_{\mathrm{T} S}$ for each sample.

\section{Results}

As it was shown in figure 1 , Real-time PCR assay was performed to evaluate the expression of the $c p s B$, $c p s D$ and $p s a A$ genes on total cDNAs related to media containing $5 \%$ Xylitol and glucose -free (Control) media. According to obtained results of and by using REST 2009 software, the automatic statistical analysis by REST 2009 software revealed that, the expression of $c p s B, c p s D$ and $p s a A$ genes was affected (see part $A$ and $B$ of Figure 1), but only the expression of $c p s B$ gene in expose with $5 \%$ Xylitol was reduced significantly in compared to the glucose free media as Control $(P=0.005)$. However, there was no significant reduction in the expression of the $c p s D$ and $p s a A$ genes.

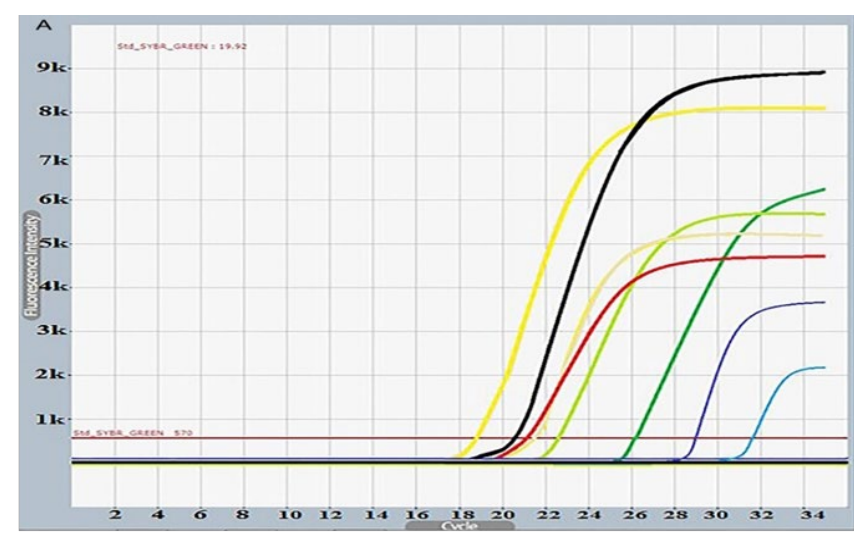

\begin{tabular}{|c|c|c|c|c|c|c|c|}
\hline \multicolumn{2}{|c|}{ Sample name } & Flu.Dve & $\mathrm{C}_{\mathrm{T}}$ & Expression & Std. Error & $95 \%$ C.I. & P(HI) \\
\hline \multirow{2}{*}{$\begin{array}{l}\text { CpsB } \\
\text { gene }\end{array}$} & $\begin{array}{c}5 \% \text { xylitol } \\
\text { treated }\end{array}$ & & 21.11 & \multirow[b]{2}{*}{$0 / 060$} & \multirow[b]{2}{*}{$0 / 020-0 / 204$} & \multirow[b]{2}{*}{$0 / 009-0 / 404$} & \multirow[b]{2}{*}{$0 / 005$} \\
\hline & control & & 20.66 & & & & \\
\hline \multirow{2}{*}{$\begin{array}{l}\text { cpsD } \\
\text { gene }\end{array}$} & $\begin{array}{c}5 \% \text { xylitol } \\
\text { treated }\end{array}$ & & 28.88 & \multirow{2}{*}{$0 / 512$} & \multirow{2}{*}{$0 / 094-6 / 637$} & \multirow{2}{*}{$0 / 017-15 / 363$} & \multirow{2}{*}{$0 / 528$} \\
\hline & control & & 31.73 & & & & \\
\hline \multirow{2}{*}{$\begin{array}{c}\text { psaA } \\
\text { gene }\end{array}$} & $\begin{array}{c}5 \% \text { xylitol } \\
\text { treated }\end{array}$ & & 18.85 & \multirow{2}{*}{$0 / 744$} & \multirow{2}{*}{$0 / 192-2 / 796$} & \multirow{2}{*}{$0 / 090$ - $8 / 399$} & \multirow{2}{*}{$0 / 611$} \\
\hline & control & & 21.77 & & & & \\
\hline \multirow{2}{*}{$\begin{array}{l}\text { aroE } \\
\text { gene }\end{array}$} & $\begin{array}{c}5 \% \text { xylitol } \\
\text { treated }\end{array}$ & & 22.47 & \multirow{2}{*}{$1 / 000$} & & & \\
\hline & control & - & 26.11 & & & & \\
\hline
\end{tabular}

Figure 1. The Cyber green RT Real Time PCR amplification has showed. Part A), the pattern of implications $c y c l e$ of $c p s B$, $c p s D$, and $p s a A$ genes in different media in this study. Part B), the results of REST 2009 software statistical analysis has shown. 
In the second set up to simultaneously evaluate the effects of Xylitol and fructose; Real-time PCR assay was carried out on total cDNAs related to medias containing 5\% Xylitol and 5\% fructose $+5 \%$ Xylitol. It's just here, Only the expression of cpsB gene was reduced and the expression of the $c p s D$ and $p s a A$ genes did not change (Figure-2). This finding also confirmed the results of previous studies that the presence of fructose in the media prevents the inhibition of Xylitol.

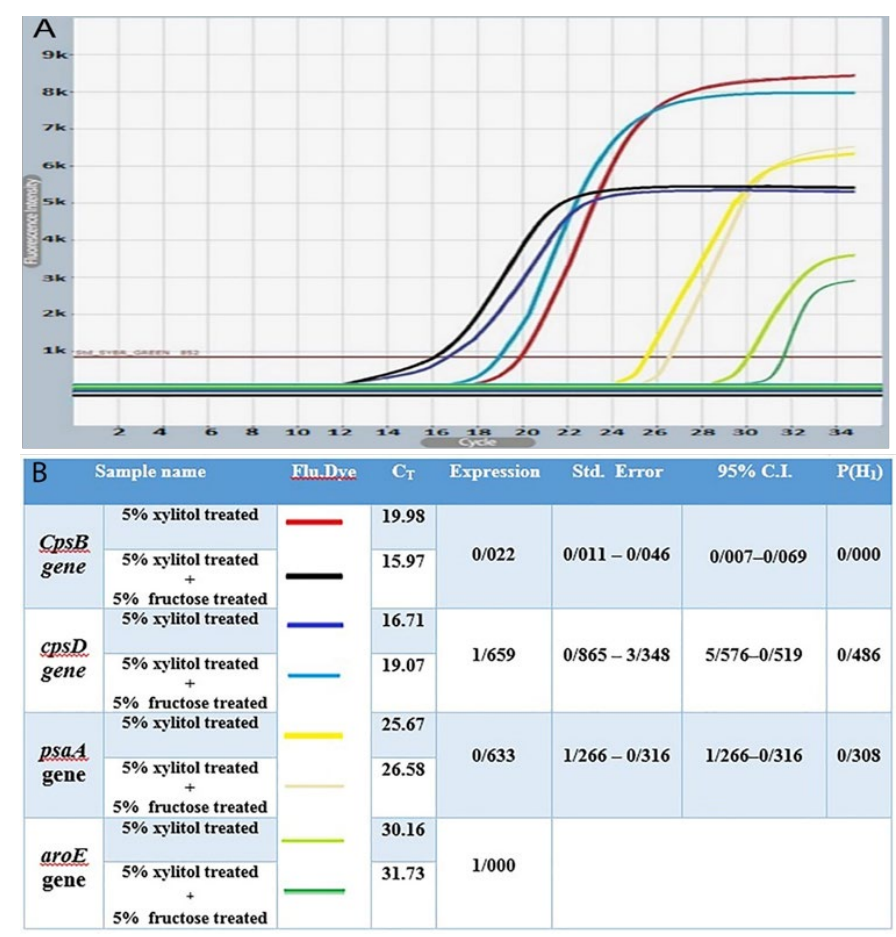

Figure 2. Part A) The resulting pattern of replication of $c p s B, c p s D$, and psaA genes in media containing $5 \%$ Xylitol compared to media containing 5\% fructose $+5 \%$ Xylitol. Part B) The REST 2009 software results statistical analysis has shown.

The analysis of melting curve also proved during the Real-Time PCR, only one specific product was amplified and there is no non-specific product and primerdimer. More than one peaks show non-specific amplification. Melting curve results of $c p s B$ gene showed that the $\mathrm{Tm}$ of the all product of this gene was equal to $82^{\circ} \mathrm{C}$ and also in the case of cpsD gene, in the analysis of melting curve only one peaks at $82^{\circ} \mathrm{C}$ was observed.

\section{Discussion}

Emerging a wide range of deadly infections by $S$. pneumonia (29) as well as the development of antibiotic resistance by this bacterium (30). Diagnosis, treatment and prevention of relative infections are global problem (31). In addition, a vaccine that can cover all pathogen strains is not yet available. Therefore, other ways to control pneumococcal infections have been considered in recent years.

One of the current hypothesis that could possibly prevent the infection from pathogenic strains is focused on the inhibition of some virulence genes.

Since the $S$. pneumonia several virulence genes that one of the most important of these genes is the polysaccharide capsule regulator genes (as the most important virulence factor) and the $p s a A$ gene, which plays a major role in bacterial binding, can be mentioned.

Therefore, $c p s B, c p s D$ and $p s a A$ genes were investigated in this study and as control, the $\operatorname{aro} E$ gene, also known as the House Keeping gene, was examined.

A published study results have shown that the fructose could prevent the inhibitory antibacterial action of Xylitol; this may be due to Xylitol entering bacteria through fructose receptors while in the absent of fructose, its inhibitory effect does not occur (19). As the same, our previous study results revealed that the presence of $5 \%$ fructose inhibit the anti- pneumococcal activity even after 24 hours (32).

Furthermore, our previous study had shown the growth pattern of bacteria based on the recorded ODs by MTT method, and concluded that the best time and concentration of the user sugars. Present study was conducted out to assay the effects of the expression of selected genes, and 3 hours after exposed of bacterial suspension to $5 \%$ Xylitol, $5 \%$ fructose $+5 \%$ Xylitol as a point out were considered. Thus, pertaining to the present study, it should be noted that in less 
than 3 hours, there is not enough time to evaluate the inhibition of the expression of genes and in more than 3 hours, the growth rate of bacterial cells will vary in different media, Therefore, the time point of 3 hours, which was equivalent to MIC concentration of the $5 \%$ Xylitol, was chosen to assessment the inhibition of the expression of the genes based on the previous study finding (32).

However, in this study based on our previous experience, we used 3 hours as a time point out for investigating the assay of inhibitory effects of utilized sugars against the selected gens expression. While, the Kuorola's research were implemented on standard strain ATCC 49619, the expression of the only $c p s B$ gene was monitored 2 hours after exposure to 5\% Xylitol and The 16SrRNA gene was also selected as the reference gene (20). In addition, the Kuorola's resea-rch were focused on one target gene expression, but in this study, we assayed four target gene. However, pertaining to the one target gene the results were the same.

According to the results of the present study, the relative expression of $c p s B$ gene in exposure to $5 \%$ Xylitol was significantly reduced ccompared with $5 \%$ glucose and control media. The outstanding of the current research was that, the results of the real-time PCR were analyzed by using REST 2009 software in order to determine the expression of $c p s B, c p s D$ and psaA genes of bacteria strains and also reference ATCC 6305 strain in 5\% Xylitol, $5 \%$ fructose $+5 \%$ Xylitol and control medias. Also the aroE gene was used as the reference gene. According to the REST 2009 software analysis (see attached Tables in Figures 1 and 2), although the expression of target genes was associated with a decrease, but the decrease in $c p s B$ gene expression was significant renege in compared to control $(P=0.005)$.

\section{References}

1. Loughran AJ, Orihuela CJ, Tuomanen El. Streptococcus pneumoniae: Invasion and Inflammation. Microbiol Spectr. 2019 Mar;7(2): 10.1128/microbiolspec.GPP3-0004-2018. [DOI:10.1128/9781683670131.ch20]

2. Luck JN, Tettelin H, Orihuela CJ. Sugar-Coated Killer: Serotype 3 Pneumococcal Disease. Front Cell Infect Microbiol. 2020 Dec 23; 10:613287. [DOI:10.3389/fcimb.2020.613287]

3. Geno KA, Gilbert GL, Song JY, Skovsted IC, Klugman KP, Jones C, Konradsen HB, Nahm MH. Pneumococcal Capsules and Their Types: Past,
By comparing these results with the results of Kuorola studies, it was observed that in the same experimental conditions, including the same volume of BHI- Broth, FBS and similar concentration of Xylitol, the expression level of $c p s B$ gene in this study was reduced significantly; the differences may be due to differences in standard bacterial strains, reference gene type, exposure duration, different quality of RNA extraction kits, cDNA synthesis, and Real-Time PCR protocols.

\section{Conclusion}

In recent years, the health benefits of using Xylitol have received much attention; not only act as an oral hygiene effects but also it stimulates the immune system. In addition, a research results have shown that the short-term consumption of Xylitol may decreasing the release of pro-inflammatory cytokines and the counts of Streptococcus mutans. Although, a plenty of research has been reported on the benefits of Xylitol, its antibacterial mechanism of action is unknown. Thus, in the present study, three genes encoding the capsular- making proteins were investigated. The main finding was that, after 3 hours' exposure to $5 \% \mathrm{Xylitol}$, the relative expression of $c p s B$ gene was reduced about $97.8 \%$ compared with control media $(P=0.005)$. This is an outstanding result, because of it may be very important and suggest the possibility of clinical use of this sugar.

\section{Acknowledgment}

The authors would like to thank the Deputy of Clinical Development Medical Center of Baqiyatallah Hospital for their support.

\section{Conflict of Interest}

The authors declared no conflict of interest.

Present, and Future. Clin Microbiol Rev. 2015 Jul;28(3):871-99. [DOI:10.1128/CMR.00024-15]

4. Ataee RA, Habibian S, Mehrabi-Tavana A, Ahmadi Z, Jonaidi N, Salesi M. Determination of vancomycin minimum inhibitory concentration for ceftazidime resistant Streptococcus pneumoniae in Iran. Annals of clinical microbiology and antimicrobials. 2014; 13:53. [DOI:10.1186/s12941-014-0053-1]

5. Ataee RA, Hossaini SMJ, Karami A, Safiri Z, Allahverdi M. Simultaneous detection of common bacterial meningitis: Neisseria meningitidis, Haemophilus influenzae and 
Streptococcus pneumonia by multiplex PCR. Trauma Monthly. 2009;14(3):119-26.

6. Ataee RA, Mehrabi Tavana A, Karami A, Izadi M, Hasani SMJ, Safiri Z, et al. The assessment of universal primer for rapid detection of bacterial meningitis. Hakim Res J. 2009;11(4):27-32.

7. Hamaguchi S, Zafar MA, Cammer M, Weiser JN. Capsule Prolongs Survival of Streptococcus pneumoniae during Starvation. Infect Immun. 2018 Feb 20;86(3): e00802-17. [DOI:10.1128/IAI.00802-17]

8. Paton JC, Trappetti C. Streptococcus pneumoniae Capsular Polysaccharide. Microbiol Spectr. $2019 \quad$ Mar;7(2). [DOI:10.1128/microbiolspec.GPP3-0019-2018]

9. Denapaite D, Hakenbeck R. A New Variant of the Capsule 3 Cluster Occurs in Streptococcus pneumoniae from Deceased Wild Chimpanzees. PLOS ONE. 2011;6(9):25119. [DOI:10.1371/journal.pone.0025119]

10. Habibian S, Mehrabi-T A, Ahmadi Z, Izadi M, Jonaidi N, Darakhshanpoure J, et al. Serotype Distribution and Antibiotics Susceptibility Pattern of Streptococcus pneumonia in Iran. Iran. Red Crescent Med J. 2013;15(10):8053. [DOI:10.5812/ircmj.8053]

11. Vos P, Garrity G, Jones D, Krieg NR, Ludwig W, Rainey FA, et al. Bergey's Manual of Systematic Bacteriology. 2nd ed. New York: 2009.704.

12. Hyams C, Trzcinski K, Camberlein $E$, M.Weinberger D,Chimalapati S,Noursadeghi M, et al. Streptococcus pneumoniae Capsular Serotype Invasiveness Correlates with the Degree of Factor $\mathrm{H}$ Binding and Opsonization with C3b/iC3b. Infect Immun. 2012;81(1):354. [DOI:10.1128/IAI.00862-12]

13. Obaro S, Adegbola R. The Pneumococcus: carriage, disease and conjugate vaccines. J Med Microbiol. 2002;51(2):98-104 [DOI:10.1099/0022-1317-51-2-98]

14. Hausdorff WP, Feikin DR, Klugman KP. Epidemiological differences among Pneumococcal serotypes. Lancet Infect Dis. 2005;5(2):39-83. [DOl:10.1016/S14733099(05)70083-9]

15. Standish AJ, Salim AA, Zhang H, Capon RJ, Morona R. Chemical Inhibition of Bacterial Protein Tyrosine Phosphatase Suppresses Capsule Production. PLoS ONE. 2012;7(5):1-3. [DOI:10.1371/journal.pone.0036312]

16. Mäkinen KK, Bennett CA, Hujoel PP, Isokangas PJ, Isotupa KP, Pape HR Jr Et al. Xylitol chewing gums and caries rates. a 40-month cohort study. J Dent Res (74). (74):1904-13. [DOI:10.1177/00220345950740121501]

17. Kontiokari T, Uhari M, Koskela M. Effect of xylitol on growth of nasopharyngeal bacteria in vitro. Antimicrob Agents Chemother. 1995 (39):18203. [DOI:10.1128/AAC.39.8.1820]

18. Kontiokari T, Uhari M, Koskela M. Antiadhesive effects of xylitol on otopathogenic bacteria. J Antimicrob Chemother. 1998 (41):563-5. [DOI:10.1093/jac/41.5.563]

19. Tapiainen $T$, Kontiokari T, Sammalkivi L, Ikäheimo I, Koskela M, Uhari M. Effect of xylitol on growth of Streptococcus pneumoniae in the presence of fructose and sorbitol. Antimicrob Agents $\begin{array}{lll}\text { Chemother. } & 2001 & \text { (45):166-9. }\end{array}$ [DOI:10.1128/AAC.45.1.166-169.2001]

20. Kurola $P$, Tapiainen $T$, Kaijalainen $T$, Uhari $M$, Saukkor iipi A. Xylitol and capsular gene expression in Streptococcus pneumoniae. Journal of Medical Microbiology. 2009; 58:14703. [DOI:10.1099/jmm.0.011700-0]

21. Russell H, Tharpe JA, Wells DE, White EH, Johnson JE. Monoclonal antibody recognizing a species-specific protein from Streptococcus pneumoniae. J Clin Microbiol. 1990; 28:2192-5. [DOI:10.1128/jcm.28.10.2191-2195.1990]

22. Sampson JS, Furlow Z, Whitney AM, Williams D, Facklam R, Carlone GM. Limited diversity of Streptococcus pneumoniae psaA among pneumococcal vaccine serotypes. Infect Immun. 1997;65(5): 1967-71. [DOI:10.1128/iai.65.5.1967-1971.1997]

23. Berry A, Paton JC. Sequence heterogeneity of PasA, a 37-kilodalton putative adhesin essential for virulence of Streptococcus pneumoniae. Infect Immun. 1996; 64:5255-62. [DOI:10.1128/iai.64.12.5255-5262.1996]

24. Morrison KE, Lake D, Crook J, Carlone GM, Ades $E$, Facklam R, et al. Confirmation of psaA in all 90 serotypes of Streptococcus pneumoniae by PCR and potential of this assay for identification and diagnosis. J Clin Microbiol. 2000;38(1): 434-7. [DOI:10.1128/JCM.38.1.434-437.2000]

25. Ataee RA, Mehrabi-Tavana A, and Esmaili D. Serotyping Distribution of Invasive Pneumococcal Disease (IPD) in Iranian patients. J Pure Appl Microbiol. 2012; 6(1): 155-160.

26. Habibian S, Mehrabi-Tavana A, Ahmadi Z, Izadi $\mathrm{M}$, Jonaidi N, Darakhshanpoure J, et al. Serotype distribution and antibiotics susceptibility pattern of Streptococcus pneumonia in Iran. Iran Red 


\section{Crescent Med J. 2013;15(10):e8053.} [DOI:10.5812/ircmj.8053]

27. Tavana AM, Ataee R, Gerami M, Gooya M, Karami A, Ranjbar $R$, et al. A study investigating the Streptococcus Pneumoniae pattern among Iranian patients. Archives of Pharmacy Practice. 2012;3(2):122. 080X.112808]

[DOI:10.4103/2045-

28. Mohsenpoor M, MehrabiTavana A, Ataee R A, Ranjbar R, Mirnejad R. Isolation and Identification of Streptococcus pneumoniae from Admitted Patients in Tehran Hospitals in during 2013-2015. Iran J Med Microbiol. 2017; 11(2):09-16.

29. Asgari A, Ataee RA, Ghorbanalizadegan $M$, MehrabiTavana A. Diagnosis of Streptococcus pneumoniae based on $c p s B, c p s D$ and psaA
Genes. J Mazandaran Univ Med Sci. 2018;28(161)121-126.

30. Kanık Yüksek S, Gülhan B, Tezer H, Özkaya Parlakay A,Uzun Kenan B, Sayed Oskovi H,et al. Invasive pneumococcal disease in two nonvaccinated pediatric cases: pleural empyema and bacteremia. Mikrobiyol Bul. 2015;49(3):446-53. [DOI:10.5578/mb.9742]

31. Hanage WP, Fraser C, Tang J, Connor TR, Corander J. Hyper-Recombination, Diversity, and Antibiotic Resistance in Pneumococcus. Science. 2009; 324;1454-7. [DOI:10.1126/science.1171908]

32. Asgari A, Ataee RA, Ghorbanalizadegan $M$, MehrabiTavana A. Effect of Xylitol on the Growth and Survival of Streptococcus pneumoniae. Jundishapur J Microbiol. 2018;11(12)e69319. 